\title{
Design, Fabrication and Evaluation of Solar and Biomass Hybrid Dryer with Trackable Solar Collector
}

\author{
C. A. Kumarasiriwardhana ${ }^{1,}{ }^{*}$, P. D. Kahandage ${ }^{1}$, G. V. T. V. Weerasooriya ${ }^{1}$
}

1 Department of Agricultural Engineering and Soil Science, Faculty of Agriculture, Rajarata University of Sri Lanka, Puliyankulama, Anuradhapura.

\section{Correspondence:}

*chathu.anuradhini@gmail.com

https://orcid.org/0000-0002-0242-8700

DOI: http://doi.org/10.4038/sljae.v2i2.45

\begin{abstract}
Newly constructed solar and biomass hybrid dryer consists of solar collector with solar tracking option, biomass backup heater and a drying chamber. The absorber of the trackable solar collector was made of black painted corrugated GI sheet and clear glass for the top. Saw dust was used as the fuel for the biomass burner. The drying chamber was built of plywood and insulated by aluminium foil. The performance was evaluated using five drying treatments with three replicates; namely, only with solar power $\left(\mathrm{T}_{1}\right)$, solar power with tracking $\left(\mathrm{T}_{2}\right)$, only with biomass $\left(\mathrm{T}_{3}\right)$, with hybrid mode $\left(\mathrm{T}_{4}\right)$, and direct sun drying ( $\mathrm{T}_{5}$; Control). Invented hybrid dryer reduced the initial moisture content of Musa spp. (banana), Artocarpus heterophyllus (jackfruit) and Pleurotus ostreatus (oyster mushroom) from $80 \%, 74 \%$ and $90 \%$ to $12 \%, 12 \%$ and $10 \%$, respectively. Under no-load condition, the average temperature of drying chamber reached to $45.04{ }^{\circ} \mathrm{C}$ with solar drying and $55.65{ }^{\circ} \mathrm{C}$ with solar tracking option, while the ambient temperature was $33.52^{\circ} \mathrm{C}$. The solar collector efficiency obtained from the no-load test was $34.07 \%$. Results revealed that the dryer can reduce the high initial moisture contents up to a safe storage moisture content within a day. With the support of the backup heater, the dryer can be used even under the inadequate solar radiation. Improper drying chamber insulation was observed as a limitation.
\end{abstract}

Key words: Biomass burner, Collector efficiency, Drying chamber, Solar collector, Solar tracking 


\section{Introduction}

In Sri Lanka, agriculture represents a considerable part of the economy. However, national food production still does not meet the demand. Crop failures, seasonal fluctuations of the production, post-harvest losses due to lack of appropriate preservation and storage system caused serious losses in national agricultural production. Drying is one of the most cost-effective way of preserving foods, which involves removal of water by application of heat (Chen et al. 2008). As a tropical country, Sri Lanka obtains adequate solar energy intensity (15-20 MJ $\mathrm{m}^{-2}$ day $^{-1}$ ) and a large number of days of sunshine (Renne et al. 2016). Solar energy is traditionally used by the food industry for drying of spices, fish, vegetables, paddy and agricultural base products. However, amount of solar energy available is not utilized in the maximum level in food production and processing industry.

Difficulties of drying during rainy and cloudy days, inadequate drying and unable to continue drying during night time, difficulties of handling as bulk drying, high labour requirement, low quality of dried product, direct contacting to sun light and contamination are the major problems of direct/open sun drying.

Although, direct sun drying method is still common in non-commercial uses at rural household level, numerous efforts has been taken to develop advanced drying methods for food processing. Exposing agricultural products to direct sun light in ambient condition as a thin layer of product is used in sun drying. During sun drying, heat is transferred to product by convection from the surrounding air by absorption of direct and diffuse solar radiation. Under the ambient conditions, the process continues until the vapour pressure of the product equals that in the atmosphere (Bux et al. 2002). Technical alternative to the traditional method of sun drying is solar drying. It involves increasing the vapour pressure and decreasing the relative humidity of the drying air in drying chamber and thereby increases the moisture carrying capacity (Vanderhulst 1990).

Bischoff (1996) reported that the thermal efficiency of modified kukum solar dryer was $13 \%$ and the thermal efficiency of dryer evaluated by Thabaraj et al. (2004) was 10\%. However, the operation and maintenance of these dryers are complicated at household 
level due to the complex structure of the dryers.

Since the sun's position in the sky changes with seasons and time of the day, solar tacking is used to increase the energy output from solar panels and solar receivers. Solar tracker follows the movement of the sun as it rotates from the east to the west daily. Solar trackers can increase the output of heat/electrical energy by $20-30 \%$ (Arinze et al. 1996). One significant limitation of a solar dryer is that it can only be used during the daytime when there is adequate solar radiation. Therefore, it is necessary to provide solar dryer with any form of back-up heating.

The present climatological and economic situation of the country demands an ecofriendly and cheap source of energy for the drying applications (Nalawade 2019). Biomass can be a source of promising renewable energy for drying agricultural commodities hence it is important application for developing countries

Market unavailability of a suitable lowcost easy handling dryer for domestic use, and the high capital and operational costs of dryers are the problems for the small-scale farmers when drying agricultural products to increase the shelf life. Therefore, this study aimed to introduce an efficient and affordable solar and biomass hybrid dryer for the preservation of agricultural products and increase the final product quality of the dried product through technical alterations.

\section{Methodology}

An indirect type solar biomass hybrid dryer was designed with four major components; solar flat plate collector, cabinet type drying chamber, biomass burner and supporting frame structure. The dryer mainly used solar radiation as the source of energy. According to the available past studies, the efficiency of solar collectors are reported to be varied from $25 \%$ to $45 \%$ (Struckmann 2008). In order to increase the drying efficiency of the solar biomass hybrid type dryer,

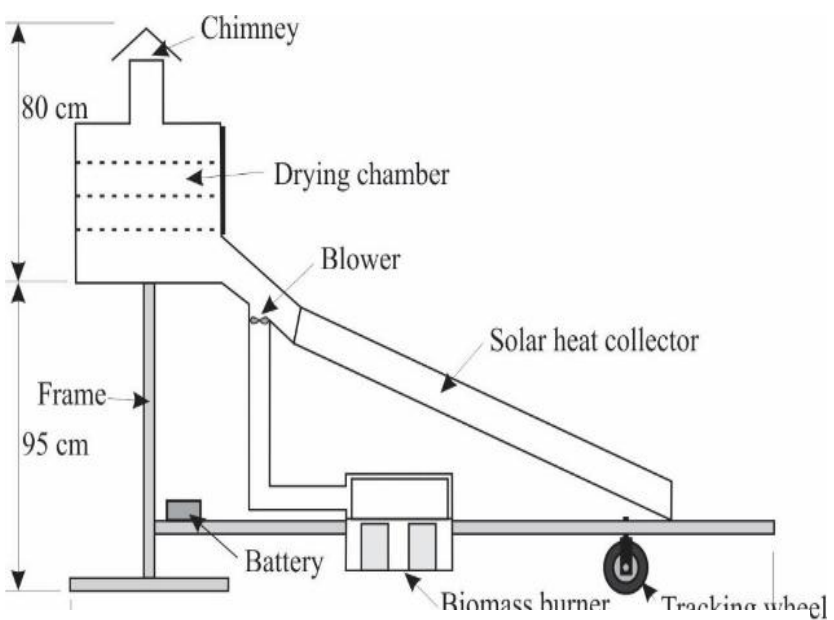

Figure. 1: Components of Solar-Biomass Hybrid Dryer 
there were several attempts such as force-feed convection and proper insulation. However, there were no evidence of using solar tracking option incorporated to the solar collector.

In this newly constructed dryer, the efficiency of the solar collector was designed to increase by tracking the sun's daily rotation. A $360^{\circ}$ rotatable solar collector attached to the iron frame occupies the solar tracking according to the sun's rotation. Other than solar energy, biomass was used as an additional means of heat supply for continuous operation in night-time, cloudy, and rainy days. Therefore, the operational mode of the dryer can be considered as hybrid. Fig. 1 shows the components of the solar biomass hybrid dryer.

\section{Designing procedure}

Following design criteria and parameters were taken into consideration at the designing stage of the solar dryer.

\section{Determination of drying temperature}

Scalin (1997) recommended drying temperatures for fruits and vegetables to be between 37.7 - $54.4{ }^{\circ} \mathrm{C}$. Higher temperature may cause browning of sugar of many fruit products when drying. Hence, $45{ }^{\circ} \mathrm{C}$ was considered as average drying temperature.

\section{Designing of the solar collector}

At the initial stage, the dryer was designed only for the experimental purpose and expected to dry only $3 \mathrm{~kg}$ of fresh banana in a batch. The size of the solar collector was designed accordingly.

\section{Determination of moisture content to be removed}

The equation 1 proposed by Hernandez et al. (2000) was used to calculate the total amount of moisture to be removed.

$$
M_{w}=\frac{W_{w}\left(M_{i}-M_{f}\right)}{1-M_{f}} \ldots \ldots \ldots . . . . .(E q .1)
$$

Where,

$M_{W}$ - amount of moisture to be removed $W_{W}$ - initial total mass

$M_{i}$-initial moisture content on wet basis $M_{f}$-final moisture content on wet basis

In the drying process, the initial and the required final moisture content of dried banana considered for the study were $77 \%$ and $14 \%$ (wet basis), respectively (FAO 1997). Therefore, amount of moisture to be removed from $3 \mathrm{~kg}$ of banana was $2.19 \mathrm{~kg}$. 
Determination of amount of heat energy required for drying

The heat required to remove water from a product was calculated using the equation 2 provided by Mercer (2007). It considers that, drying as a two-stage process where the first stage is raising the temperature of the wet material to a desired level at which the moisture is removed. The amount of heat required for first stage $\left(Q_{1}\right)$ is given by the $E q .2$.

$$
Q_{1}=W_{w} \times C_{p} \times T \text {. }
$$

Where,

$W_{W}$-initial weight

$C_{p}$-specific heat capacity of the product $\left(\mathrm{kJ} \mathrm{kg}^{-1}{ }^{\circ} \mathrm{C}^{-1}\right)$

$\mathrm{T}$-temperature change $\left({ }^{\circ} \mathrm{C}\right)$

$C_{p}$ value of the Eq.2 was considered as $3.35 \mathrm{~kJ} \mathrm{~kg}^{-1}{ }^{\circ} \mathrm{C}^{-1}$ (Chaiwanichsiri et al. 1993). Therefore, $Q_{1}$ was calculated as follows;

$Q_{1}=3 \mathrm{~kg} \times 3.35 \mathrm{~kJ} \mathrm{~kg}^{-1}{ }^{\circ} \mathrm{C}^{-1} \times(45-32){ }^{\circ} \mathrm{C}$

$Q_{1}=130.65 \mathrm{~kJ}$

The second stage is evaporating the moisture from the product. As water starts to evaporate after the product is warmed up to the drying temperature, the heat required to evaporate $\left(Q_{2}\right)$ is given by Eq.3.
$Q_{2}=M w \times L$

Where,

$M_{W}$ - amount of moisture to be removed

$L$ - latent heat of vaporization

Accordingly;

$Q_{2}=2.19 \mathrm{~kg} \times(2256) \mathrm{kJ} \mathrm{kg}^{-1}$

$Q_{2}=4940.64 \mathrm{~kJ}$

Therefore, the theoretical total heat requirement is the summation of $Q_{1}$ and $Q_{2}(5071.29 \mathrm{~kJ})$. It does not take into account the heat losses through the walls of the dryer or the heat leaving the dryer through the chimney.

\section{Determination of the size for the solar collector}

The daily average insolation of Anuradhapura is taken as $4.71 \mathrm{kwh} \mathrm{m}^{-2}$ day $^{-1}$ (PVwatts 2017). According to Struckmann (2008), the typical flat-plate collector efficiency (at ambient temperature of $25^{\circ} \mathrm{C}$ and $\mathrm{I}=400 \mathrm{~W} \mathrm{~m}^{-2}$ ) is in between $25 \%$ and $45 \%$. The collector efficiency is influenced by factors such as temperature, airflow rate, insolation, type of transparent material, absorber plate and insulation used (Struckmann 2008). To achieve an optimal design, the average value of collector efficiency was considered as $35 \%$. 
Therefore, the daily expected energy extraction by the collector

$$
\begin{aligned}
& =(4.71 \times 3600) \mathrm{kJ} \mathrm{m}^{-2} \mathrm{day}^{-1} \times 0.35 \\
& =5.9346 \mathrm{MJ} \mathrm{m}^{-2}
\end{aligned}
$$

Since the total heat energy required for drying is $5.9346 \mathrm{MJ}$,

$$
\begin{aligned}
\text { Collector Area } & =\frac{5.07129 \mathrm{MJ}}{5.9346 \mathrm{MJ} / \mathrm{m}^{2}} \\
& =0.8545 \mathrm{~m}^{2}
\end{aligned}
$$

Considering the heat losses as $15 \%$, the area of the collector was decided as $1 \mathrm{~m}^{2}$.

Forson et al. (2007) suggested the aspect ratio of a solar collector to be 1:3. Therefore, the length and width of the collector were determined as $1.7 \mathrm{~m}$ and $0.6 \mathrm{~m}$, respectively.

\section{Collector orientation and tilt angle}

Since the experimental location Puliyankulama, Anuradhapura (Latitude $8^{0} 33^{\prime} \mathrm{N}$ and longitude $80^{\circ} 42^{\prime}$ E) a collector tilt angle of $27^{0}\left(8^{0} 33^{\prime}+19^{0}\right)$ was considered to track the maximum solar radiation during the day time. This tilt angle also helped to avoid the accumulation of rainwater on the collector during rainy periods and facilitate the natural conventional flow.

\section{Air flow requirement}

Scalin (1997), has recommended air velocity to be between $0.51 \mathrm{~m} \mathrm{~s}^{-1}$ to 5.08 $\mathrm{m} \mathrm{s}^{-1}$. In addition, the depth of the air channel should be $\frac{1}{15}$ to $\frac{1}{20}$ of the length of collector. Taking the average factor of the depth of the air channel (0.058) as suggested by Scalin (1997);

Depth of air channel $=$ Average factor of depth of air channel $\times$ Length of the collector

$=0.058 \times 1.7 \mathrm{~m}=0.0986 \mathrm{~m} \approx 10 \mathrm{~cm}$

Vent Area $=$ Width of collector $\times$ Air gap

$$
\begin{aligned}
& =60 \mathrm{~cm} \times 10 \mathrm{~cm} \\
& =600 \mathrm{~cm}^{2}=0.06 \mathrm{~m}^{2}
\end{aligned}
$$

Volume flow rate $=$ Vent Area $\times$ Air Velocity

$$
\begin{aligned}
& =0.06 \mathrm{~m}^{2} \times 0.51 \mathrm{~m} \mathrm{~s}^{-1} \\
& =0.0306 \mathrm{~m}^{3} \mathrm{~s}^{-1}
\end{aligned}
$$

Mass flow rate

$=$ volume flow rate $\times$ air density

$$
=0.0306 \mathrm{~m}^{3} \mathrm{~s}^{-1}
$$

$\times 1.2 \mathrm{~kg} \mathrm{~m}^{-3}=0.03672 \mathrm{~kg} \mathrm{~s}^{-1}$

This mass flow rate value lies between the range of $0.02-0.9 \mathrm{~kg} \mathrm{~s}^{-1}$, as recommended by Forson et al. (2007) for natural convection dryers. 
Determination of dimensions for the drying chamber

The capacity of the drying chamber was decided to dry $3 \mathrm{~kg}$ of banana on three trays. Length and width of a tray was decided as $0.5 \mathrm{~m}$ and $0.45 \mathrm{~m}$, respectively. According to Tibebu 2015, the gap between two trays was adjusted to $15 \mathrm{~cm}$ and the gap between bottom plate to the tray was taken as $20 \mathrm{~cm}$. Hence, designed dimensions of the drying chamber were $0.45 \mathrm{~m}$ in width, $0.5 \mathrm{~m}$ in length and $0.65 \mathrm{~m}$ in height.

\section{Designing of biomass burner}

As a backup heat source, a biomass burner was designed to operate when there is no enough solar radiation in night-time and during rainy times that fluctuating the solar radiation due to the clouds cover. Two burning cylinders designed for incineration of the sawdust and an air circulation section was designed to generate heated air.

Flat metal plates get heated by the heat generated by sawdust burning. A series of vertical metal plates fixed on that flat plate facilitate more surface area. Air circulate inside that plate series get heat and generate convection current. Heated air is delivered to the drying chamber through insulated metal tube connected to the burner. The other end of the metal tube close to the drying chamber is connected with a force feed blower powered by 12 V, 4 A battery.

Fabrication of the solar-biomass hybrid dryer

Fabrication of the dryer was done at the Engineering Workshop, Faculty of Agriculture, Rajarata University of Sri Lanka. Several factors; such as availability, workability, strength were considered when selecting material for the design (Khurmi and Gupta 2006). Table 1, shows the selected material and selection criteria.

\section{Evaluation of the dryer}

\section{Material preparation for drying}

Fresh ripe banana (local variety 'Embul') obtained from the local market were peeled and sliced. Matured unripe Jackfruit bulbs were sliced. Tender parts of oyster mushroom (caps) were sliced and stalks were cut into short sections.

As reported SolarFlex (2013), slices of fresh food should not be more than $5 \mathrm{~mm}$ thick. Therefore, approximate slice thickness of $3 \mathrm{~mm}$ was used for banana and jackfruit. Blanching was done for 
jackfruit and banana as a pre-treatment $\left(60{ }^{\circ} \mathrm{C} / 3\right.$ minutes).

Table 1: Materials selection for the SolarBiomass Hybrid dryer

\begin{tabular}{|c|c|c|}
\hline Component & $\begin{array}{l}\text { Criteria for } \\
\text { selection }\end{array}$ & $\begin{array}{l}\text { Selected } \\
\text { material }\end{array}$ \\
\hline $\begin{array}{l}\text { Frame of the } \\
\text { dryer }\end{array}$ & $\begin{array}{l}\text { Strength, } \\
\text { Workability }\end{array}$ & $\begin{array}{l}\text { Mild steel } \\
\text { (angled } \\
\text { iron) }\end{array}$ \\
\hline $\begin{array}{l}\text { Biomass } \\
\text { burner }\end{array}$ & $\begin{array}{l}\text { Heat } \\
\text { transmission, } \\
\text { Strength, Cost }\end{array}$ & Mild steel \\
\hline Collector top & $\begin{array}{l}\text { Transparency, } \\
\text { Lightness }\end{array}$ & Glass \\
\hline Collector base & $\begin{array}{l}\text { Heat absorption, } \\
\text { Strength, } \\
\text { Lightness, } \\
\text { Corrosion and } \\
\text { acidic reaction } \\
\text { resistance }\end{array}$ & $\begin{array}{l}\text { Galvanized } \\
\text { corrugated } \\
\text { steel }\end{array}$ \\
\hline $\begin{array}{l}\text { Drying } \\
\text { chamber }\end{array}$ & $\begin{array}{l}\text { Strength, cost, } \\
\text { Heat resistance } \\
\text { availability }\end{array}$ & Ply wood \\
\hline Drying trays & $\begin{array}{l}\text { Strength, } \\
\text { wear resistance }\end{array}$ & $\begin{array}{l}\text { Plastic } \\
\text { coated steel }\end{array}$ \\
\hline Chimney & $\begin{array}{l}\text { Strength, } \\
\text { Workability }\end{array}$ & Mild steel \\
\hline
\end{tabular}

\section{Treatments}

T1 -Only solar drying (with solar heat collector orientated to north - south direction)

T2 - Only solar drying with solar tracking option (with time rotate the solar heat collector to track maximum solar radiation)
T3 - Only biomass energy drying (biomass burner operate with saw dust burning)

T4 - Hybrid mode (solar energy with solar tracking option together with biomass burner operate as additional heat supply)

T5 - direct sun drying in open area with available sun light (Control).

Testing and evaluations were conducted on sunny days on June and July 2017. Thus, the effect of weather variations was minimal due to no rainy or considerable cloudy days during the period.

\section{Performance evaluation of dryer}

In no-load test, the temperature in the dryer was measured without drying materials. The temperature variation in collector output, drying chamber chimney outlet and ambient temperature were recorded in 20 minutes intervals. The no-load test was conducted for all treatments to test the maximum possible temperature rise in the drying chamber compared to the corresponding ambient temperature.

In addition to the no-load test, performance of the dryer was measured with agricultural products (Jack fruit, banana and mushroom) for all the 
treatments. Initial sample weight, temperature, humidity, wind speed and solar insolation were measured during the evaluation. The temperature and humidity inside the dryer and ambient were measured using wet and dry bulb thermometers placed inside the drying chamber and near the inlet of solar heat collector. Outlet air temperature was measured using a thermometer placed at the chimney outlet. Relative humidity was obtained referring the psychrometric chart. Moisture content was measured at every 20 minutes interval. The significance of the treatments were tested in terms of drying time, drying rate and drying efficiency using General Lineal Model procedure (GLM) of Statistical Analysis System (SAS) software version 9.0 at $0.05 \alpha$ level. The mean separation was done using, Duncan New Multiple Range Test (DNMRT). Efficiency of the solar collector and the biomass burner were determined.

\section{Results and Discussion}

The solar-biomass hybrid dryer was fabricated according to the design and evaluated for performances. The total production cost of the solar-biomass hybrid dryer was 21,000.00 LKR including all the material and labour cost. The fabricated dryer is shown in Fi. Plate 1, and its components; solar collector, biomass burner and drying chamber are shown in Plate 2, 3 and 4, respectively.

Several types of solar hybrid dryers have been designed and evaluated to dry agricultural products. Among them, Prasad et al. (2005) reported the fabrication and test results of an integral-type natural convection of direct solar dryer coupled with a biomass stove. The overall drying efficiency of the system for drying ginger in the night mode was $7.1 \%$. In 2002, Bena et al. studied a hybrid drying system, which consisted of a direct-type natural convection solar drying cabinet mounted on top of a brick chamber that enclosed a simple biomass burner and obtained overall 6\% drying efficiency for pineapple in the night mode. In their indirect type natural convection solar dryer integrated with collector-storage solar and biomass back-up heaters Madhlopa et al. (2007) obtained overall $11 \%$ drying efficiency for drying pineapple in the night mode. As discussed above, overall drying efficiency of the solar biomass hybrid dryers were low in previous studies. Newly invented solar biomass hybrid 
dryer showed better performances in drying portably due to the solar tracking. The average drying efficiency was found to be $11.73 \%$ (banana), $13.17 \%$ (jackfruit) and 7.96\% (mushroom). Efficiency increment due to the solar tracking was $39.79 \%$.

In addition, the drying efficiency when the backup heater is used as the hybrid mode was 13.22\% (banana), 14.95\% (jackfruit) and 8.77\% (mushroom) was observed. This value same when compared with the study done by Barkiet al. (2012), where the average drying efficiency for a dryer was $13 \%$ with an incinerator that uses charcoal as a feed material. Comparing the efficiency with solar drying without tracking and the efficiency when operate in hybrid mode with backup heater and solar tracking showed $57.16 \%$ increment in efficiency.

This newly constructed dryer aimed to increase the drying efficiency of the dryer by adding a solar trackable collector as the sun's daily rotation. Solar collector with solar tracking option and the additional heat supplying biomass burner connected to the dryer is a novel design for small scale dryer.

\section{Results of evaluation tests}

The results of the no-load test carried out to find the actual variation of temperature in the drying chamber during the day time is shown in Fig. 2.

During the day time, when the solar without tracking $\left(\mathrm{T}_{1}\right)$ was the only source of heat supply, the maximum temperature of the drying chamber had recorded as $53{ }^{\circ} \mathrm{C}$ while the average temperature was $39.48{ }^{\circ} \mathrm{C}$. When the solar was used with tracking $\left(\mathrm{T}_{2}\right)$, the maximum temperature in the chamber was $56^{\circ} \mathrm{C}$ while the average temperature was $45.04{ }^{\circ} \mathrm{C}$. The maximum and average temperatures of the hybrid mode $\left(\mathrm{T}_{4}\right)$ were $60{ }^{\circ} \mathrm{C}$ and $51.26{ }^{\circ} \mathrm{C}$, respectively. The maximum rise in temperature of the drying chamber was about $18.04{ }^{\circ} \mathrm{C}$ compared to the ambient temperature. A similar value was reported by Svenneling (2012) for an indirect type of dryer where the temperature rises in the dryer reached $50{ }^{\circ} \mathrm{C}$ at midday. 


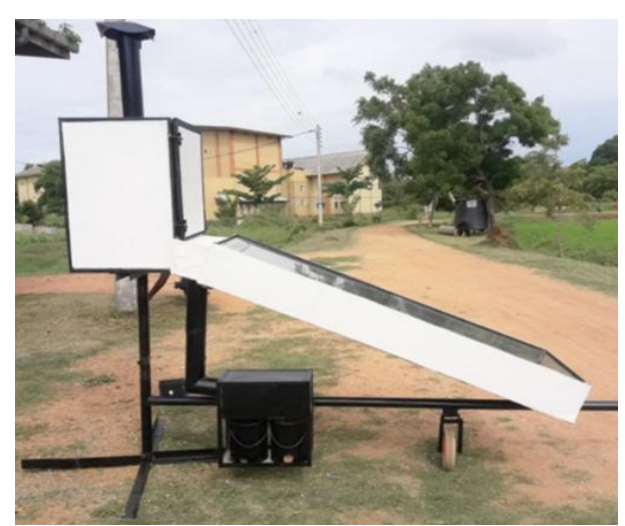

Plate 1: Solar-Biomass Hybrid Dryer

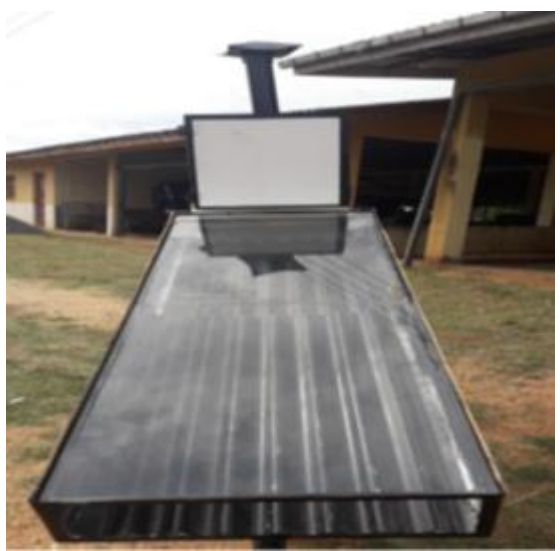

Plate 2: Solar Collector

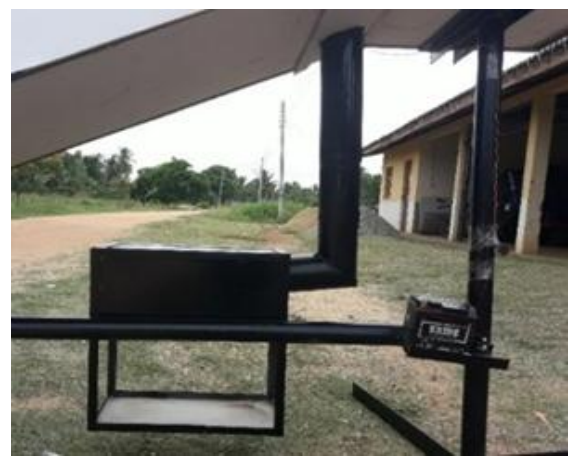

Plate 3: Biomass Burner

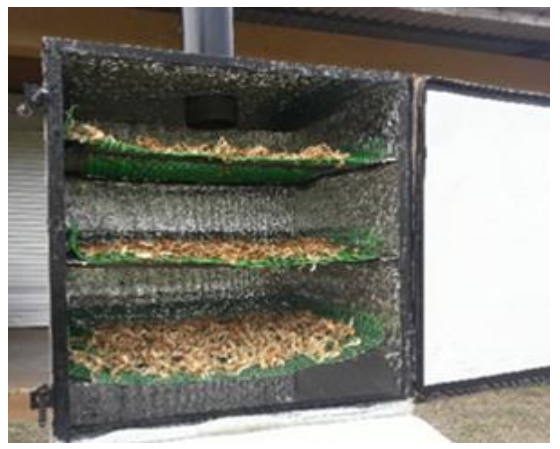

Plate 4: Drying Cabinet
The average temperature of the drying chamber when dryer operate at hybrid mode $\left(\mathrm{T}_{4}\right)$ was higher than an indirect type dryer constructed by Antwi (2007) which reported an average temperature elevation of $6.9{ }^{\circ} \mathrm{C}$. A similar no-load indirect type dryer test performed by Tibebu (2015) resulted in a maximum temperature elevation of $15.5{ }^{\circ} \mathrm{C}$ when dryer operated with solar energy while Charcoal was used as the feedstock on the stove as backup heater in hybrid mode. According to Mercer (2007) the best drying temperature is in the range of $50{ }^{\circ} \mathrm{C}$ to $55{ }^{\circ} \mathrm{C}$ for most food products. Moreover, the temperature should not exceed $60{ }^{\circ} \mathrm{C}$ due to destruction of nutrients. The maximum chamber temperature raised to $60^{\circ} \mathrm{C}$ in the hybrid mode $\left(\mathrm{T}_{4}\right)$ with solar tracking option. Results clearly showed that the dryer operates within the maximum allowable temperature range $\left(50{ }^{\circ} \mathrm{C}\right.$ to $\left.55^{\circ} \mathrm{C}\right)$ for fruit and vegetable drying.

The hybrid mode $\left(\mathrm{T}_{4}\right)$ recorded the significantly lowest drying time with the mean value of 6.77 hours (Table 2). Results prove that when the dryer operated 


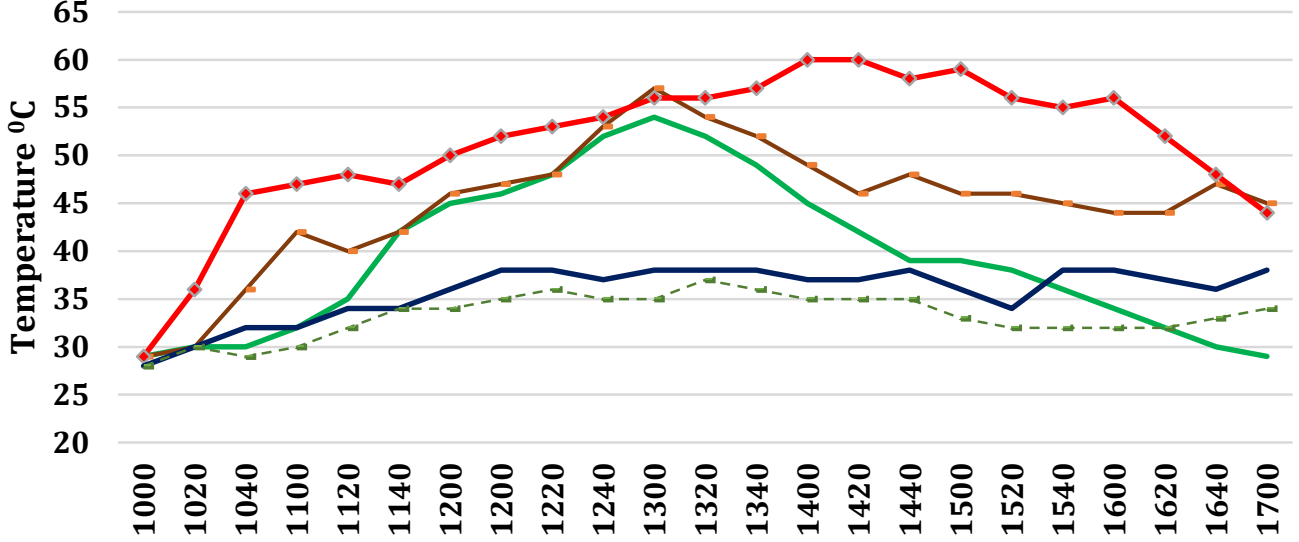

Time (24h)

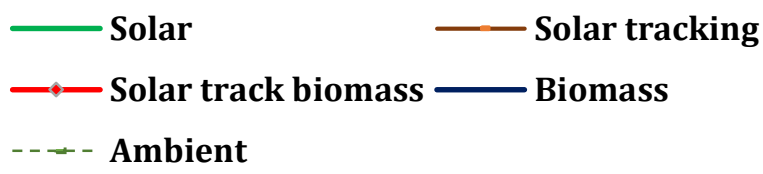

Figure 2: Drying chamber temperature variation in no load test

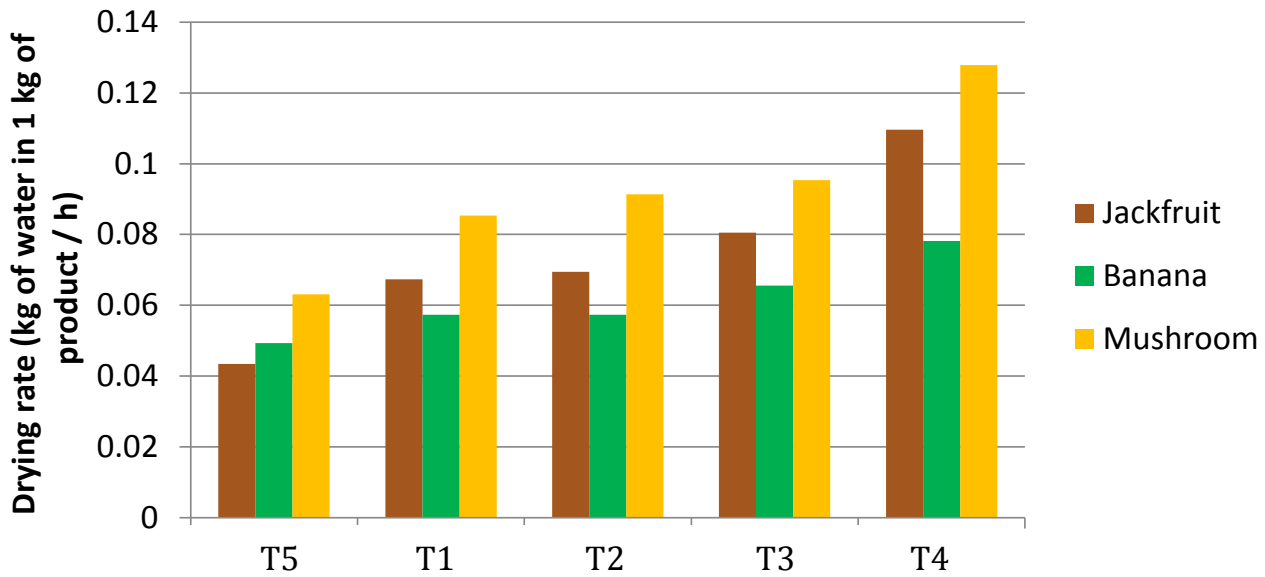

Figure 3: Moisture removing rates of different products under different drying methods

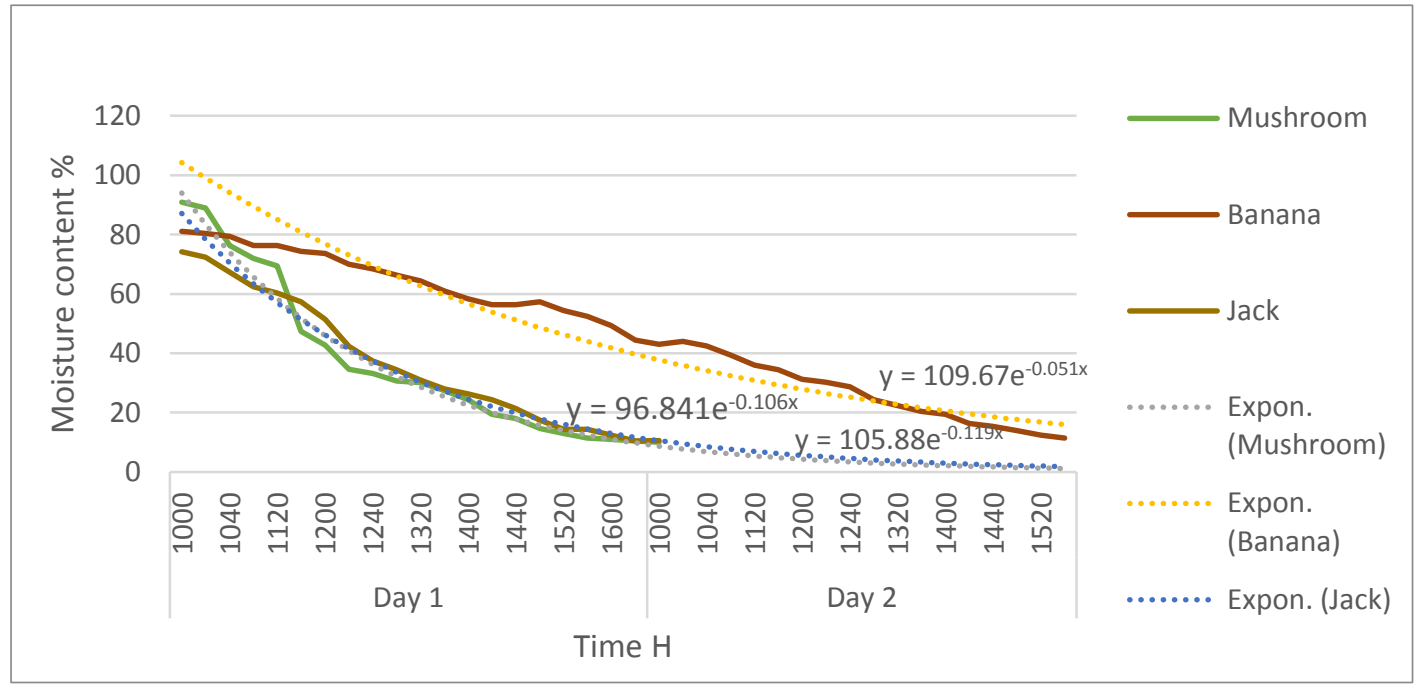

Figure 4: Moisture content variation in hybrid drying method 
with the solar and biomass hybrid operation together with the solar tracking option, the product dry within a one sunny day ( $8 \mathrm{~h}$ ) time period which is advantageous for the farmers. Inability to dry the product within a day can lead to easy spoilage and reduce quality of the dried product. Continuity of drying process avoid contamination and spoilage of product specially during night time.

Table 2: Variation of mean drying time of different treatments

\begin{tabular}{|c|l|}
\hline Treatment & $\begin{array}{l}\text { Drying time } \\
(\mathrm{h})\end{array}$ \\
\hline $\mathrm{T}_{1}$ & $9.80^{\mathrm{b}}$ \\
\hline $\mathrm{T}_{2}$ & $8.68^{\mathrm{c}}$ \\
\hline $\mathrm{T}_{3}$ & $13.60^{\mathrm{b}}$ \\
\hline $\mathrm{T}_{4}$ & $6.77^{\mathrm{d}}$ \\
\hline $\mathrm{T}_{5}$ & $13.60^{\mathrm{a}}$ \\
\hline
\end{tabular}

$\mathrm{T}_{1}$-Solar without tracking, $\mathrm{T}_{2}-$ Only solar drying with solar tracking option, $\mathrm{T}_{3}$ - Only biomass energy drying, $\mathrm{T}_{4}-$ Hybrid mode, $\mathrm{T}_{5}$ - direct sun drying (Control). Means followed by different letters are significantly different at $p \leq 0.05$ according to DNMRT.

Drying time was significantly lower when applying tracking option compared to solar drying without tracking (T1).

\section{Moisture removing rates of different drying methods}

The moisture removing rates for the different drying methods are presented in Fig. 7.
According to the Fig. 3, when solar is used with tracking and backup heater as hybrid mode the highest drying rates for banana, jackfruit and mushroom were $0.781 \mathrm{~kg}$ of water in $1 \mathrm{~kg}$ of product per hour, $0.109 \mathrm{~kg}$ of water in $1 \mathrm{~kg}$ of product per hour and $0.127 \mathrm{~kg}$ of water in $1 \mathrm{~kg}$ of product per hour, respectively. According to the Ringeisen (2014) drying rate of a cabinet type solar dryer directly associated with the chamber temperature, humidity and the ventilation system that remove moisture air inside the dryer.

As shown in Fig. 4, the exponential trend line equations were derived. The time taken to obtain the final moisture content when dryer operate in hybrid mode with tracking option were calculated and presented in Table 3.

Table 3: Drying Time when dryer operate in Hybrid mode with solar tracking option

\begin{tabular}{|l|l|l|}
\hline & $\begin{array}{l}\text { Trend line } \\
\text { equation }\end{array}$ & $\begin{array}{l}\text { Drying } \\
\text { time (h) }\end{array}$ \\
\hline Banana & $\mathrm{y}=109.67 \mathrm{e}-0.051 \mathrm{x}$ & 8.46 \\
\hline Jackfruit & $\mathrm{y}=96.841 \mathrm{e}-0.106 \mathrm{x}$ & 6.566 \\
\hline Mushroom & $\mathrm{y}=105.88 \mathrm{e}-0.119 \mathrm{x}$ & 6.609 \\
\hline Mean drying time & 6.8 \\
\hline
\end{tabular}


Table 4: Variation of drying efficacy in different treatments

\begin{tabular}{|c|l|}
\hline Treatment & $\begin{array}{l}\text { Drying } \\
\text { efficiency }\end{array}$ \\
\hline $\mathrm{T}_{1}$ & $7.83^{\mathrm{c}}$ \\
\hline $\mathrm{T}_{2}$ & $10.95^{\mathrm{b}}$ \\
\hline $\mathrm{T}_{3}$ & $8.65^{\mathrm{c}}$ \\
\hline $\mathrm{T}_{4}$ & $12.31^{\mathrm{a}}$ \\
\hline
\end{tabular}

$\mathrm{T}_{1}$-Solar without tracking, $\mathrm{T}_{2}$ - Only solar drying with solar tracking option, $\mathrm{T}_{3}$ - Only biomass energy drying, $\mathrm{T}_{4}$ - Hybrid mode, Means followed by different letters are significantly different at $p \leq 0.05$ according to DNMRT.

When dryer operated with solar tracking option ( $\left.\mathrm{T}_{2}\right)$ and operated in hybrid mode $\left(\mathrm{T}_{4}\right)$ dryer showed significantly higher drying efficiency while, the hybrid mode obtained significantly the highest drying efficiency. This efficiency data showed significant different compared to drying done in solar without tracking $\left(\mathrm{T}_{1}\right)$, and drying with biomass burning only $\left(\mathrm{T}_{3}\right)$ (Table 4).

\section{Solar collector efficiency of the dryer}

The efficiency of the solar collector was calculated for the no load test as equation 04, (Struckmann, 2008).

$\eta=\frac{v \rho \Delta T C_{p}}{I_{c} \times A_{c}} \times 100 \ldots . . .(E q 4$.

Where,

$\mathrm{v}=$ volumetric flow rate of air $\mathrm{kg} \mathrm{m}^{-3}$

$\rho=$ air density $\mathrm{kg} \mathrm{m}^{-3}$

$\mathrm{T}=$ air temperature elevation ${ }^{\circ} \mathrm{C}$

$\mathrm{C}_{\mathrm{p}}=$ air specific heat capacity $\mathrm{J} \mathrm{kg}^{-1}{ }^{\circ} \mathrm{C}^{-1}$

$\mathrm{I}_{\mathrm{c}}=$ insolation on collector surface $\mathrm{w} \mathrm{m}^{-2}$
$\mathrm{A}_{c}=$ collector area $\mathrm{m}^{2}$

$\mathrm{V}=0.4 \mathrm{~km} \mathrm{~h}^{-1}$

$$
\begin{gathered}
\mathrm{V}=\frac{0.4 \times 1000 \times 60 \times 10^{-2} \times 15 \times 10^{-2}}{3600} \\
=0.01 \mathrm{~m}^{3} \mathrm{~s}^{-1}
\end{gathered}
$$

$\mathrm{A}=1.105 \mathrm{~m}^{2}$

$\rho=1.225 \mathrm{~kg} / \mathrm{m}^{3}$

$\mathrm{C}_{\mathrm{p}}=1.00608 \mathrm{kj} \mathrm{kg}^{-1}{ }^{0} \mathrm{C}(318 \mathrm{~K})$

$\Delta \mathrm{T}=6{ }^{\circ} \mathrm{C}$

$\mathrm{I}_{\mathrm{c}}=4.71 \mathrm{kwh} \mathrm{m}^{-2}$ day $^{-1}=4.71 \times 0.1142 \times$

$365.25=196.4214005 \mathrm{w} \mathrm{m}^{-2}$

$\eta=\frac{0.01 \times 1.225 \times 6 \times 1.00608 \times 10^{3}}{196.421 \times 1.105} \times 100$

$=34.06 \%$

Solar collector efficiency of this dryer $(34.06 \%)$ is in accordance with Struckmann (2008) that is comparable with the typical flat-plate collector efficiency $(25 \%$ - 45\%). Collector efficiency of $46.6 \%$ reported by Saravanan et al. (2014). Bolaji (2005) also reported a collector efficiency of $60.5 \%$ for a box-type absorber collector. Newly designed flat plate solar collector has a lower efficiency level compared to the above studies. This might due to the heat losses of the solar collector. The efficiency could be increased by applying good insulation method to minimize heat losses. 


\section{Efficiency of the biomass burner}

The overall thermal efficiency of the biomass burner can be defined as the ratio of useful heat transferred to the drying air to the energy potential of fuel (Bena and Fuller 2002).

Biomass burning stove fuel consumption rate (M) calculated considering the average drying time of 7 hours as follows;

$\mathrm{M}=\frac{6 \mathrm{~kg}}{7 \times 3600}=0.238 \times 10^{-3} \mathrm{~kg} \mathrm{~s}^{-1}$

The biomass burner efficiency when use sawdust as the burning fuel was calculated using the no load test using Equation 05;

$\eta=\frac{v \rho \Delta T C_{p}}{M \times S} \times 100$

$\mathrm{V}=14.4 \mathrm{~km} \mathrm{~h}^{-1}$

$\mathrm{V}=\frac{\pi\left(10^{-2}\right)^{2} 14.4 \times 1000}{3600}=0.125 \mathrm{~m}^{3} \mathrm{~s}^{-1}$

$\rho=1.225 \mathrm{~kg} \mathrm{~m}^{-3}$

$\mathrm{C}_{\mathrm{p}}=1.00608 \mathrm{kj} \mathrm{kg}^{-1}{ }^{0} \mathrm{C}^{-1}(318 \mathrm{~K})$

$\Delta \mathrm{T}=9^{0} \mathrm{C}$

$\mathrm{S}=17.98 \mathrm{Mj} \mathrm{kg}^{-1}$

$\eta=\frac{0.125 \times 1.2259 \times 1.00608 \times 10^{3}}{17.98 \times 10^{6} \times 0.238} \times 100$

$\eta=26.56 \%$

An overall efficiency of the back-up heater was $40 \%$ in a dryer designed by Tibebu (2015) when burning paddy husk as the burning fuel. Results showed that the biomass burner of the newly designed dryer has low efficiency (26.56\%).

Heat losses from the air ventilation system and duct system has identified as the major reasons and suggested to insulate the side walls and the duct system of the air circulation system.
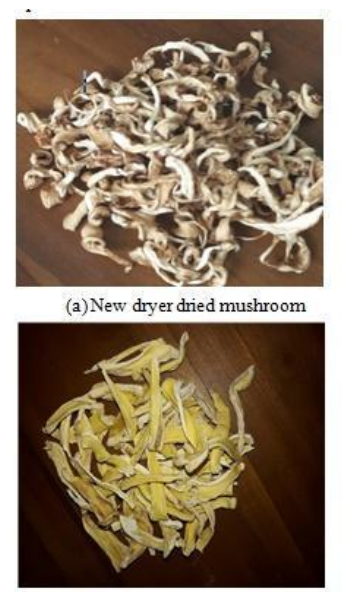

(c) New dryer dried Jackfruit

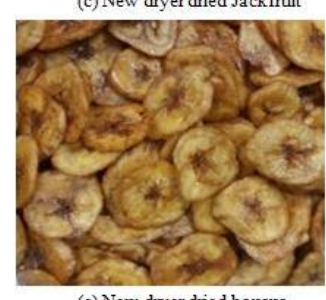

(e) New dryer dried banana

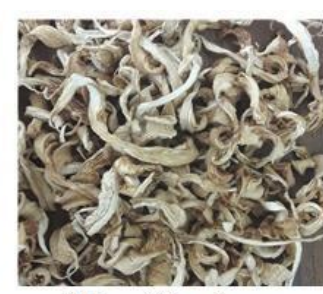

(b) Oven dried mushroom

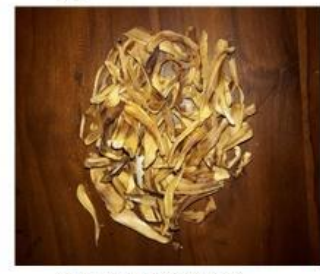

(d) Oven dried jackfruit

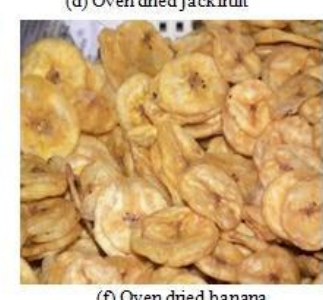

(f) Oven dried banana
Plate 5: Comparison of products dried compared to electrical oven dried product

\section{Quality of the dried product}

Quality of the dried products under hybrid mode of the dryer were compared with the products dried by electrical oven drying method due to unavailability of an electrical hot air dehydrator though it is more 
comparable method for the visual comparison.

Electrical oven that operated at $70{ }^{\circ} \mathrm{C}$ for $12 \mathrm{~h}$ period was used for the evaluation test. The Plate 5 shows the visual comparison of three products, ( mushroom, jackfruit and banana) dried by newly designed hybrid dryer and electrical oven. Though the electrical oven drying is efficient considering the drying time, due to the higher temperature, colour of the final product of electrical drying has much altered than the newly designed dryer. It is suggested that newly designed solar and biomass hybrid dryer preserves the colour of the final product which is highly affected to the food quality.

The present study mainly considered the agricultural engineering concepts including the machine design and development. However, the final product quality parameters like sensory qualities, water activity, colorimetric analysis, rehydration capacity, rehydration rates were not evaluated, which was a limitation of the study.
Hence, it is suggested to conduct future studies on the evaluation of the final product quality parameters.

\section{Conclusions}

The newly designed solar and biomass hybrid dryer with the solar tracking option can be recommended for drying of agricultural products such as , Musa spp. (banana), Artocarpus heterophyllus (jackfruit) and, Termitomyces currhizus (oyster mushroom) of a capacity of $3 \mathrm{~kg}$ per batch. The collector efficiency obtained from no load test was 34\%. Therefore, the dryer operating temperature ranged between 50-60 ${ }^{\circ} \mathrm{C}$. Further it has the ability to dry low dense moist product such as sliced banana and jackfruit, within a sunny day. Available backup heat biomass burner can facilitate drying in cloudy and rainy seasons. Due to the low production cost (21,000.00 LKR) compared to market available electrical and fuel dryers and simplicity of fabrication, this solarbiomass hybrid dryer can be popularized in Sri Lanka to preserve foods. 


\section{References}

Antwi K I (2007) Comparative Study of Hybrid Solar-gas Crop Dryer. M.Sc Thesis. University of Cape Coast, Ghana. Available at <http://ir.ucc.edu.gh/ dspace/handle/123456789/441> accessed on: 02 September 2017

Arinze E A, Sokhansanj S, Schoenau G J, and Trauttmansdorff F G (1996) Experimental evaluation, simulation and optimisation of a commercial heated-air batch hay drier. J AgriEng Res 63: pp 301-314.

Barkiet E, Ibrahim J S and Eloka-Eboka A C (2012) Performance Evaluation of an Efficient Solar Dryer with a Backup Incinerator for Grated Cassava under Makurdi Humid Climate. International Journal of Environment and Bioenergy, 2(2): pp 131-139.

Bena B, Fuller R J (2002) Natural convection solar dyer with biomass back-up heater, Solar Energy, 72: pp 7583.

Bischoff J (1996) Technology transfer and application in relation to coconut industry. Proceeding of the $33^{\text {rd }}$
COCOTEC meeting, APCC, Malaysia. Pp 15-19.

Bolaji B O (2005) Development and Performance Evaluation of a Box-type Absorber Solar Air Collector for Crop Drying. Journal of Food Technology, 3(4): pp 595-600.

Bux M, Muhlabauer W, Bauer $\mathrm{K}$ and Kohler B (2002) Solar crop drying in development countries, Available at $<$ https://www.researchgate.net/publica tion/314515397>. Accessed on: 22march 2017.

Chaiwanichsiri S, Laohasongkram K, Thunpithayakul C and Mekmanee S (1993) Thermophysical Properties of Fresh and Frozen Pineapples: Proceedings of Engineering Properties of Foods Workshop, Bangkok, Thailand, September pp 22-24.

Chen X D, Mujumdar A S (2008) Drying Technologies in Food Processing, WileyBlackwell, West Sussex UK.

FAO (1997) Food and Agricultural Organization. Fruit Processing Toolkit: 
Dried Fruit. In-Pho, (FA0), New York. pp 13-24.

Forson F K, Nazha M A A, Akuffo F O and Rajkaruna H (2007) Design of MixedMode Natural Convection Solar Crop Dryers: Application of Principles and Rules of Thumb. Journal of Renewable Energy, 32(14): pp 2306-2319.

Hernandez J A, Pavon G and Garcia M A (2000) Analytical solution of mass transfer equation considering shrinkage for modelling food-drying kinetics. Journal of food engineering, 45(1): pp 110.

Khurmi R S and Gupta J K (2006) A Text Book of Machine Design. New Delhi: Eurasia Publishing House (PVT.) LTD, Ram Nagar, pp 341-968.

Madhlopa A, Ngwalo G (2007) Solar dryer with thermal storage and biomassbackup heater. Solar Energy 2007, 81(4), 449-462.

Mercer D G (2007) An intermediate course in food dehydration and drying.Department of Food Sceience, University of Guelph, Ontario, Canada.2007,Available on <elearning.iufost.org/sites/default/files
/Intermediate-Outline-1.pdf>. accessed on 30 June 2017.

Nalawade R, and Panwar N L (2019) Experimental Investigation on Biomass Fired Dryer for Drying of Agricultural Products. International Journal of Ambient Energy, pp 1-12.

Prasad J and Vijay V (2005) Experimental studies on drying of Zingiber officinale, Curcuma longa L. and Tinospora cordifolia in solar-biomass hybrid drier. Renewable Energy 2005, 30(14), pp 2097-2109.

PVWatts (2017) PVWatts Calculator Alliance for sustainable Energy, Available on, <pvwatts.nrel.gov/> accessed on 12 June 2017.

Renne D, George R, Marion B, Heimiller D and Gueymard C (2016) Solar Resource Assessment for Sri Lanka and Maldives. United States. doi:10.2172/15004299. Available at https://www.osti.gov/servlets/purl/15 004299. Accessed on 2 July 2018.

Ringeisen B M, Barrett D and Stroeve P (2014) Concentrated Solar Drying of Tomatoes. Journal of Energy for Sustainable Development, 19: pp 47-55. 
Saravanan D, Wilson $\mathrm{V} \quad \mathrm{H}$ and Kumarasamy S (2014) Design and Thermal Performance of the Solar Biomass Hybrid Dryer for Cashew Drying. Journal of Mechanical Engineering, 12(3): pp 277-288.

Scalin D (1997) The Design, Construction and Use of an Indirect, Through-pass, Solar Food Dryer, Home Power Magazine, 57: pp 62-72.

SolarFlex (2013) Drying Fruits and Vegetables with the SolarFlex Dryer. Technical Specifications of SolarFlex Small Farm Dryer. Available from<http://www.postharvest.org/Dryi ng Fruits and Vegetable with the SolarFlex Dryer>. Available on 15 April 2017.

Struckmann F (2008) Analysis of a Flatplate Solar Collector. Project Report: 2008 MVK 160, Heat and Mass Transport. Lund University, Lund, Sweden.
Svenneling J (2012) Constructing a Solar Dryer for Drying of Pineapples: Implementing a Solar Dryer for Sustainable Development in Ghana.Karlstands University, Netherlands.

Thabaraj T, Dharmasena D A N and Samarajeewa U (2004) Development of a rotary Hybrid Dryer for Small scale Copra Processing, Tropical Agricultural research, Postgraduate Institute of Agriculture, University of Peradeniya, Peradeniya, Sri Lanka.

Tibebu T B (2015) Design, construction and evaluation of performance of solar dryer for drying fruit, Department of Agricultural Engineering, Kwame Nkrumah University of Science and Technology, Ghana.

Vanderhulst P (1990) Solar drying-small scale application in developing countries, Amsterda. 